Article

\title{
Scenario-Based Analysis on Water Resources Implication of Coal Power in Western China
}

\author{
Jiahai Yuan *, Qi Lei, Minpeng Xiong, Jingsheng Guo and Changhong Zhao \\ School of Economics and Management, North China Electric Power University, Chang Ping District, \\ Beijing 102206, China; E-Mails: hnricky06@126.com (Q.L.); xmp21@sina.com (M.X.); \\ gjs1408@sina.com (J.G.); zchh21@126.com (C.Z.) \\ * Author to whom correspondence should be addressed; E-Mail: yuanjiahai@ncepu.edu.cn; \\ Tel.: +86-10-6177-3091.
}

External Editor: Bing Xue

Received: 20 August 2014; in revised form: 10 October 2014 / Accepted: 10 October 2014 / Published: 16 October 2014

\begin{abstract}
Currently, 58\% of coal-fired power generation capacity is located in eastern China, where the demand for electricity is strong. Serious air pollution in China, in eastern regions in particular, has compelled the Chinese government to impose a ban on the new construction of pulverized coal power plants in eastern regions. Meanwhile, rapid economic growth is thirsty for electric power supply. As a response, China planned to build large-scale coal power bases in six western provinces, including Inner Mongolia, Shanxi, Shaanxi, Xinjiang, Ningxia and Gansu. In this paper, the water resource implication of the coal power base planning is addressed. We find that, in a business-as-usual (BAU) scenario, water consumption for coal power generation in these six provinces will increase from 1130 million $\mathrm{m}^{3}$ in 2012 to 2085 million $\mathrm{m}^{3}$ in 2020 , experiencing nearly a double growth. Such a surge will exert great pressure on water supply and lead to serious water crisis in these already water-starved regions. A strong implication is that the Chinese Government must add water resource constraint as a critical point in its overall sustainable development plan, in addition to energy supply and environment protection. An integrated energy-water resource plan with regionalized environmental carrying capacity as constraints should be developed to settle this puzzle. Several measures are proposed to cope with it, including downsizing coal power in western regions, raising the technical threshold of new coal power plants and implementing retrofitting to the inefficient cooling system, and reengineering the generation process to waterless or recycled means.
\end{abstract}


Keywords: energy-water nexus, coal power generation, water resource, China

\section{Introduction}

The extensive development mode in China has led to rapid economic growth in a short time, but has been followed by a lot of environmental problems, especially air pollution, in recent years. Taking the increasingly serious air pollution into consideration, the Chinese government announced the ban on new energy-and-pollution intensive projects in eastern regions, among which coal-fired power plants are strictly banned [1].

Meanwhile, China's rapid economic growth has brought growing electricity demand. The national total electricity consumption has ballooned from 2481 trillion Watt hour (TWh) in 2006 to $4200 \mathrm{TWh}$ by 2010 , with an average annual growth of $11.1 \%$ during the 11th Five-year-plan (FYP) period (2006-2010). Then in 2012, it reached $4950 \mathrm{TWh}$ [2]. In 2020, the total electricity consumption is expected to reach around $8000 \mathrm{TWh}$, with an average annual growth rate of $6.8 \%$ [3].

In order to meet the growing energy demand, five comprehensive energy bases located in Shanxi, Ordos, Xinjiang region, and eastern and southwestern Inner Mongolia will be built, according to the 12th FYP [4]. The 12th Energy Development plan also intended to develop 14 large coal mine bases and 16 coal power bases, and the total size of thermal power capacity is expected to reach more than $600 \mathrm{GW}$ in these bases $[5,6]$.

However, the water resource constraint in the coal power bases and the implication of the coal power bases on regional water resource is not fully considered in the planning. This paper is an attempt to address these two interweaved issues. The structure of the paper is as follows. Section 1 presents the background and purpose of the study. Section 2 will briefly review the water-energy nexus and provide background information on water resource and consumption in China's coal power base provinces. Section 3 will propose the model for analyzing water usage of thermal power generation. Section 4 will analyze the demand and impact of the coal power planning on water resource in China's coal power base provinces. Section 5 will provide analysis on water saving measures and an alternative scenario and Section 6 concludes the paper.

\section{Literature Review and Research Background}

\subsection{Energy-Water Nexus}

Globally, $80 \%$ of electricity generation comes from thermo-electric power stations (such as fossil fuels and nuclear), all of which require cooling for efficient and safe operation [7]. Most of the cooling system is provided by water abstractions from, and thermal discharges to, the natural environment, including rivers, tidal estuaries and coasts. The production of energy requires large quantities of water in processes such as thermal plant cooling systems or raw materials extraction. Analysis on whether water resources in a given region can support energy production will be a critical issue in the near future. The energy-water nexus has been a topic of increasing importance in recent years. In 2003 and 2006, numerous power plants in Europe had to be throttled in summer due to water shortages and high water 
temperatures caused by a hot and dry summer [8]. The agriculture sector currently has the highest water demand at the global scale, followed by the industry-energy sector that is responsible for $20 \%$ of the total water withdrawals [9]. In the U.S., the energy sector is expected to be the fastest growing water consuming sector, being responsible for $85 \%$ of the increase in domestic water consumption during 2005-2030 [10]. In some MENA (Middle Eastern and Northern Africa) countries, the interdependencies are already being manifested. For instance, in Saudi Arabia almost all of the natural gas currently produced is consumed domestically, primarily in the petrochemical industry and in seawater desalination [11]. Joint consideration of both water and energy domains can identify new options for increasing overall resource use efficiencies [12]. Gleick calculated the water consumption of different forms of energy [13]. Morgan Bazilian et al. (2011) considered the energy, water and food nexus, primarily from a developing country perspective [14]. Hagen Koch et al. described how to integrate the calculation of water demand of power plants into water resource management model [15]. Alexander et al. [16] studied the relationship between water and energy in an interactive lifecycle framework. Benjamin et al. [17] highlighted the most likely locations of severe water shortages in 22 counties because of thermoelectric capacity additions, and identified an assortment of technologies and policies that could respond to these electricity-water tradeoffs. Edward et al. [18] presented a model that quantifies current water use of the UK electricity sector, disaggregated by generation type, cooling method and cooling source. Also, it tested six decarbonisation pathways for the UK by combining projections of cooling methods and cooling sources for future thermoelectric generation. Aurelie et al. [19] proposed a model to assess optimal "water-energy" mix considering opportunities for water reuse and non-conventional water use in the water-scarce Middle East region. Kuishuang et al. [20] applied an integrated hybrid LCA approach to eight different electricity generation technologies in China to calculate their total life-cycle $\mathrm{CO}_{2}$ emissions and water consumption throughout national supply chains.

China is a drought-hit country. Though total freshwater resources reach 2.8 trillion $\mathrm{m}^{3}$, accounting for $6 \%$ of global water resources, ranking fourth in the world after Brazil, Russia and Canada, per capita water resource is just $2200 \mathrm{~m}^{3}$, a quarter of the world average, or 1/5 of the United States level [21]. Energy and water have become major factors limiting sustainable development in China. Energy efficiency and optimization of water management are critical for the healthy growth of the Chinese economy [22]. In addition to energy shortages, China is also confronted with numerous water resource challenges, including shortage, pollution and aquatic environment deterioration.

It is noteworthy that the development of China's coal power base is uncoordinated with the distribution of water resources. The coal-rich regions often face water scarcity, while regions with plentiful water resources mostly face coal shortage [23]. According to the 12th Energy Development Plan [5], coal and energy supply in China is relying on the west coal-rich regions, but these areas are mostly located in the dry arid and semi-arid regions. That is to say, water resource conditions will inevitably become an important factor in the development of coal power bases. Because of limited freshwater resources, decision-making has to take the most valuable use of this limited resource into consideration. In water-stressed areas of the coal power bases, power plants will increasingly compete with other water users. Large-scale coal power bases in arid region of northwest will lead to severe water crisis, and the conflicts between coal resources and water are most significant in the following six provinces (autonomous regions), including Inner Mongolia, Shanxi, Shaanxi, Xinjiang, Ningxia and 
Gansu. To the best scope of our knowledge, only a book [24] explicitly addressed this issue, but it only raised a question and did not provide a solution to it. It is rightly the study scope of this paper.

\subsection{Water Resources in China's Western Coal Power Base Provinces}

According to the China Statistical Yearbook 2013, the data of water resources and water use of the main coal power bases is reported in Figure 1. In terms of total water resources, Xinjiang is the richest while Ningxia is the poorest region in these provinces. In particular, the water use in Ningxia is much more than its total water resources, indicating that water is scarce. Though the water resource in Xinjiang Uygur Autonomous Region seems rich, the water resources in Hami (coal power base) is merely 1.696 billion $\mathrm{m}^{3}$, accounting for only $2.13 \%$ of its total water resource endowment [24].

Figure 1. The water resources and water use in China's coal-power base provinces.

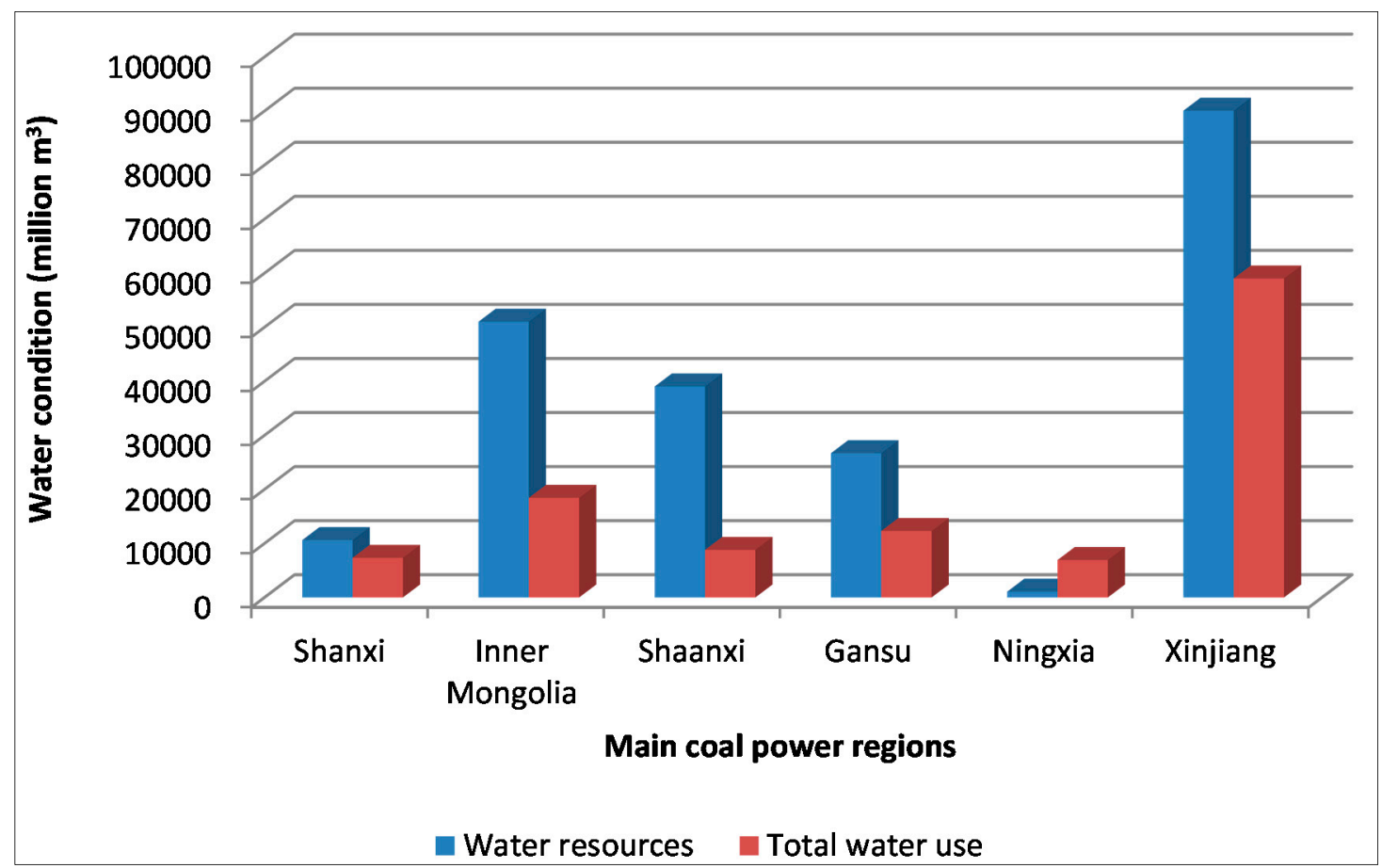

As is shown in Figure 1, the water resource in Inner Mongolia Autonomous Region is second to that of Xinjiang, but its coal power bases' water resources are not as rich. With the exception of Hulunbeir coal power base, other bases all have water shortage issues at varying degrees. For example, water resource in Jungar coal power base account for just $0.67 \%$ of Inner Mongolia water endowment [25]. For Xilingol League coal power base, the figure is 5.8\%, for Ordos coal power base, $5.4 \%$ [26], and for Holingol coal power base, $0.09 \%$ [27]. The coal power bases located in the other four provinces all have water shortage issues. Especially, the condition of water shortage in Ningxia is the most serious, whose water resource ranked the last in this country.

\subsection{Water Use in the Coal Power Base Provinces of Western China}

The consumption of water resources can be divided into the following categories: agricultural water use, household water use, ecological water use and industrial water use. The electricity sector is one of 
the largest water consumers in China after agriculture [28]. Thus, the electricity sector can be a contributor to water scarcity which has already occurred in many parts of the country, in particular in Northern China [29]. The water use of the main coal power base provinces in 2012 is shown in Figure 2 [30].

From Figure 2, we can easily see that agricultural water use absolutely takes up the most part of whole water use, and industrial use is only second to agricultural use. Though total water use in Shanxi and Shaanxi is not as much as that in Xinjiang, their industrial water use has accounted for much larger share. Because of water shortage and agricultural water demand, Ningxia does not seem to have enough water to support industry development, including coal power bases. Considering total water resources and water use, the potential of developing coal power bases in Shanxi, Gansu and Ningxia does not look optimistic.

Figure 2. Water use of main coal power base provinces in 2012.

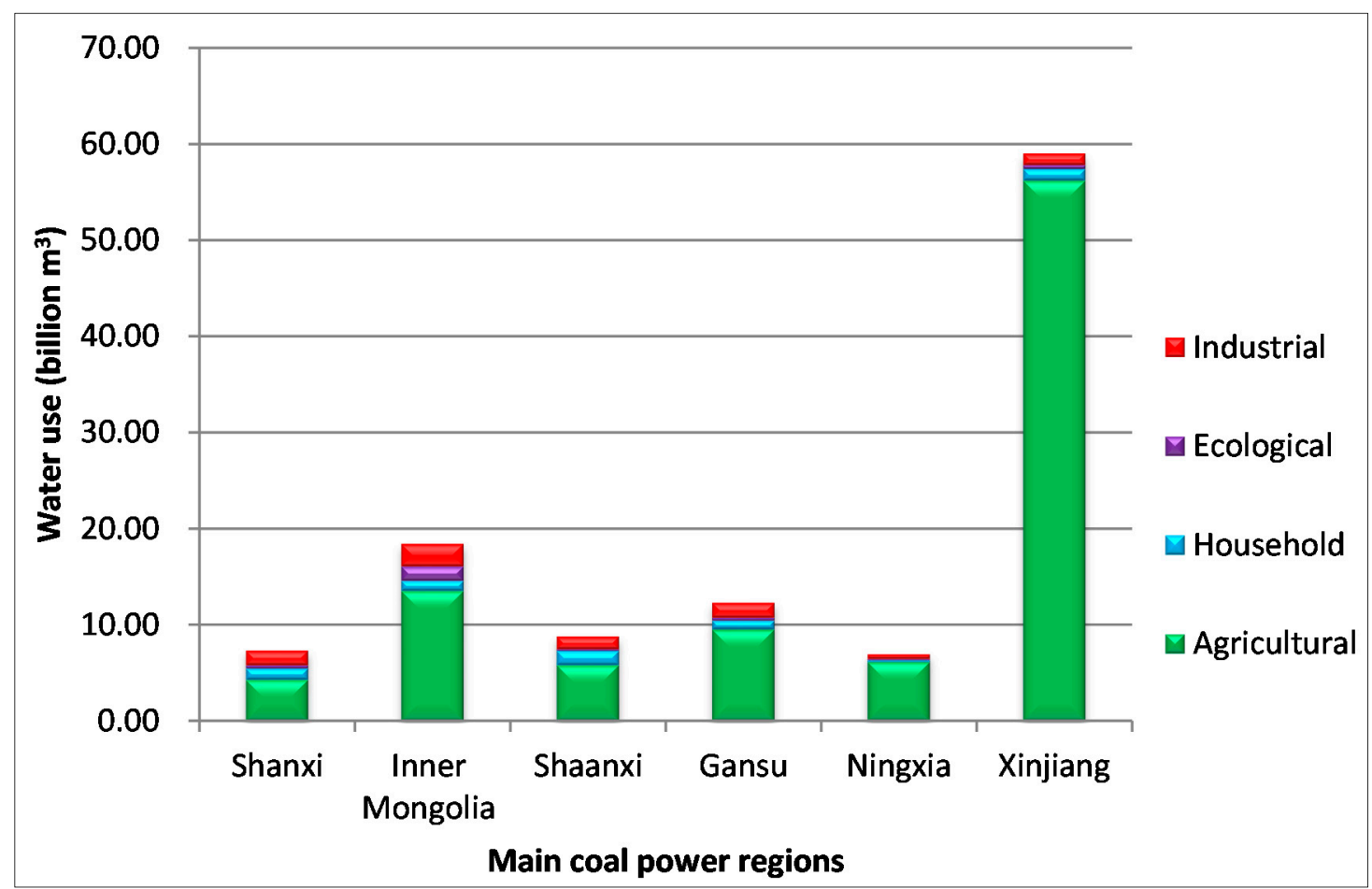

\subsection{Originality and Novelty of the Study}

The energy-water nexus has been a topic of increasing importance in recent years. Indeed, water is needed for the energy sector (fuel production and electricity generation), and energy is used to clean, desalinate and transport water. This relationship is referred to as the water-energy nexus, a concept originally formulated by Gleick in the 1990s with his seminar study [13]. Current studies and research mainly focus on water issues and energy consumption related to water management, and coupled water and energy challenges have been described for the energy production sector, i.e., for the United States [31], Australia [32], Spain [33], the UK [18], Middle East [19], and China [22]. However, though few studies have indicated that China could face water shortages resulting from the addition of thermoelectric power plants, no precise estimate or policy study have been conducted. The goal of the present study is to reveal the potential water issues in China's coal power bases, and to provide a solution for it. 


\section{Methods and Data}

According to the US Geological Survey's (USGS) water use survey data, Each kilowatt-hour (kWh) of thermoelectric generation requires the withdrawal of approximately 25 gallons of water (weighted-average for all thermoelectric power generation), which is primarily used for cooling purposes. Power plants also use water for operation of flue gas desulfurization (FGD) devices, ash handling, wastewater treatment, and wash water [34].

When discussing water and thermoelectric generation, it is necessary to distinguish between water withdrawal and water consumption. Water withdrawal represents the total water taken from a source but then returned to it, while water consumption represents the amount of water withdrawal that is not returned to the source. Water withdrawal is defined as the removal of water from any source or reservoir for human use. The water withdrawal constitutes the conveyance losses, consumptive use and return flow. Water consumption is defined as the amount of water extracted from a source that is no longer available for use, because it has evaporated, transpired, been incorporated into products and crops, consumed by man or livestock, ejected into the sea, or otherwise removed from freshwater resources [33]. The industry chain of large coal bases includes coal mining industry, thermal power industry and coal chemical industry. The focus of this paper is on the water consumption of thermal power industry and thus the terminology of "water consumption" is used in our analysis.

\subsection{The Water Link of Thermal Power Plant}

The composition of water consumption in thermal power plants are as follows: (a) water recharge of the cooling system; (b) ash and slag removal system; (c) boiler water feed system; (d) auxiliary cooling system; (e) desulfurization system; (f) water use of coal yard; and (g) domestic water use [35].

Thermal plants use fossil fuels to generate electricity or heat, and their water needs can vary drastically depending on the type of plant, type of refrigeration system, type of fuel and region [36]. The amount of water withdrawal and consumption depends on the type of technology used at a given plant. According to Meldrum et al. [37], water used for cooling purposes dominated the life cycle water use of electricity generation.

Large quantities of cooling water are required for thermoelectric power plants to support the generation of electricity. There are basically three types of cooling system designs: wet recirculating (open-loop and closed-loop) and dry recirculating (air-cooled). Open-loop (once-through) systems do not consume large quantities of water but require large quantities of water withdrawal in the cooling process. Closed-loop systems require smaller withdrawal of water, but most of the water withdrawal is lost in evaporation [13]. Air-cooled systems, also referred to as dry recirculating cooling systems, use either direct or indirect air-cooled steam condensers. In a direct air-cooled steam condenser, the turbine exhaust steam flows through air condenser tubes that are cooled directly by conductive heat transfer using a high flow rate of ambient air that is blown by fans across the outside surface of the tubes. Therefore, cooling water is not used in the direct air-cooled system. In an indirect air-cooled steam condenser system, a conventional water-cooled surface condenser is used to condense the steam, but an air-cooled closed heat exchanger is used to conductively transfer the heat from water to ambient air [38]. 


\subsection{Water Consumption Rate in Coal Power Plants}

China Electricity Council (CEC) is responsible for energy efficiency benchmarking in the power industry and releases detailed energy efficiency and water efficiency statistics [39]. By collating and analyzing the data, we calculated the water consumption and coal consumption indexes for power generation in the $600 \mathrm{MW}$ units. Table 1 reports the water consumption rates while Table 2 reports the heat rates of the coal power units with different cooling system (Interested readers may refer to the Appendix for detailed information).

Table 1. Water consumption rates in China's 600 MW coal power units, 2012.

\begin{tabular}{|c|c|c|c|c|c|}
\hline \multirow{2}{*}{$\begin{array}{c}\text { Types of cooling } \\
\text { system }\end{array}$} & \multirow{2}{*}{$\begin{array}{c}\text { Counted } \\
\text { units }\end{array}$} & \multirow{2}{*}{ Proportion (\%) } & \multicolumn{3}{|c|}{ Comprehensive water consumption rate $\left(\mathrm{m}^{3} / \mathrm{MWh}\right)$} \\
\hline & & & Optimal value & The top $30 \%$ average & Average \\
\hline Closed-loop & 128 & $39.26 \%$ & 0.23 & 1.27 & 1.83 \\
\hline Open-loop & 134 & $41.10 \%$ & 0.02 & 0.18 & 0.29 \\
\hline Air-cooled & 64 & $19.63 \%$ & 0.18 & 0.23 & 0.31 \\
\hline
\end{tabular}

Table 2. Heat rates in China's 600 MW coal power units, 2012.

\begin{tabular}{ccccc}
\hline \multirow{2}{*}{ Types of cooling system } & \multirow{2}{*}{ Counted units } & \multicolumn{3}{c}{ Heat rates (gce/kWh) } \\
\cline { 3 - 5 } & & Optimal value & The top 30\% average & Average \\
\hline Closed-loop & 128 & 285.00 & 296.41 & 307.80 \\
Open-loop & 134 & 275.85 & 290.28 & 303.89 \\
Air-cooled & 64 & 306.90 & 320.86 & 331.18 \\
\hline
\end{tabular}

As shown in Table 2, on the average, air-cooled unit performs worst in energy efficiency, with about 25 grams coal equivalent gce/kWh more than water-cooled units; while open-loop water cooling system is with lowest heat rate. Combining the information reported in Tables 1 and 2, we can easily see that the open-loop system is the most efficient, because of the lowest heat rate and the lowest comprehensive water consumption rate. However, the pre-condition for open-loop water-cooled system is the existence of large body of fresh water like rivers or lakes adjacent to the power plant. Also, the direct pollution of freshwater also indicates the infeasibility of open-loop water-cooled system.

\subsection{Method}

According to the data on installed capacity and comprehensive water consumption rates of thermal power plants by [39], we can calculate the water consumption of thermal power plants in these coal power bases located in western provinces. The water consumption of power plants is calculated by:

$$
\mathrm{Q}=\sum_{\mathrm{i}=1}^{3} \mathrm{MW}_{\mathrm{i}} \times \mathrm{H}_{\mathrm{i}} \times \mathrm{R}_{\mathrm{i}} \div 10^{6}
$$

where

Q water consumption $\left[10^{6} \mathrm{~m}^{3} / \mathrm{a}\right]$

MW installed capacity of thermal power plants [MW]

$\mathrm{H} \quad$ Annual operation hours of the thermal power plants 
$\mathrm{R}$ comprehensive water consumption rate $\left[\mathrm{m}^{3} / \mathrm{MWh}\right]$

$\mathrm{i}=1 \quad$ closed-loop cooling system

$\mathrm{i}=2 \quad$ open-loop cooling system

$\mathrm{i}=3 \quad$ air-cooled cooling system

The methodology for water consumption estimate and scenario study is presented in Figure 3. In its simplest form, water consumption is calculated by multiplying the electricity generated from a certain technology and the consumption factor for that technology, which is subject to various assumptions in our study. Because of the scope of our study, we limit our study in the above-mentioned six western coal power base provinces.

Figure 3. Methodology framework of our study.

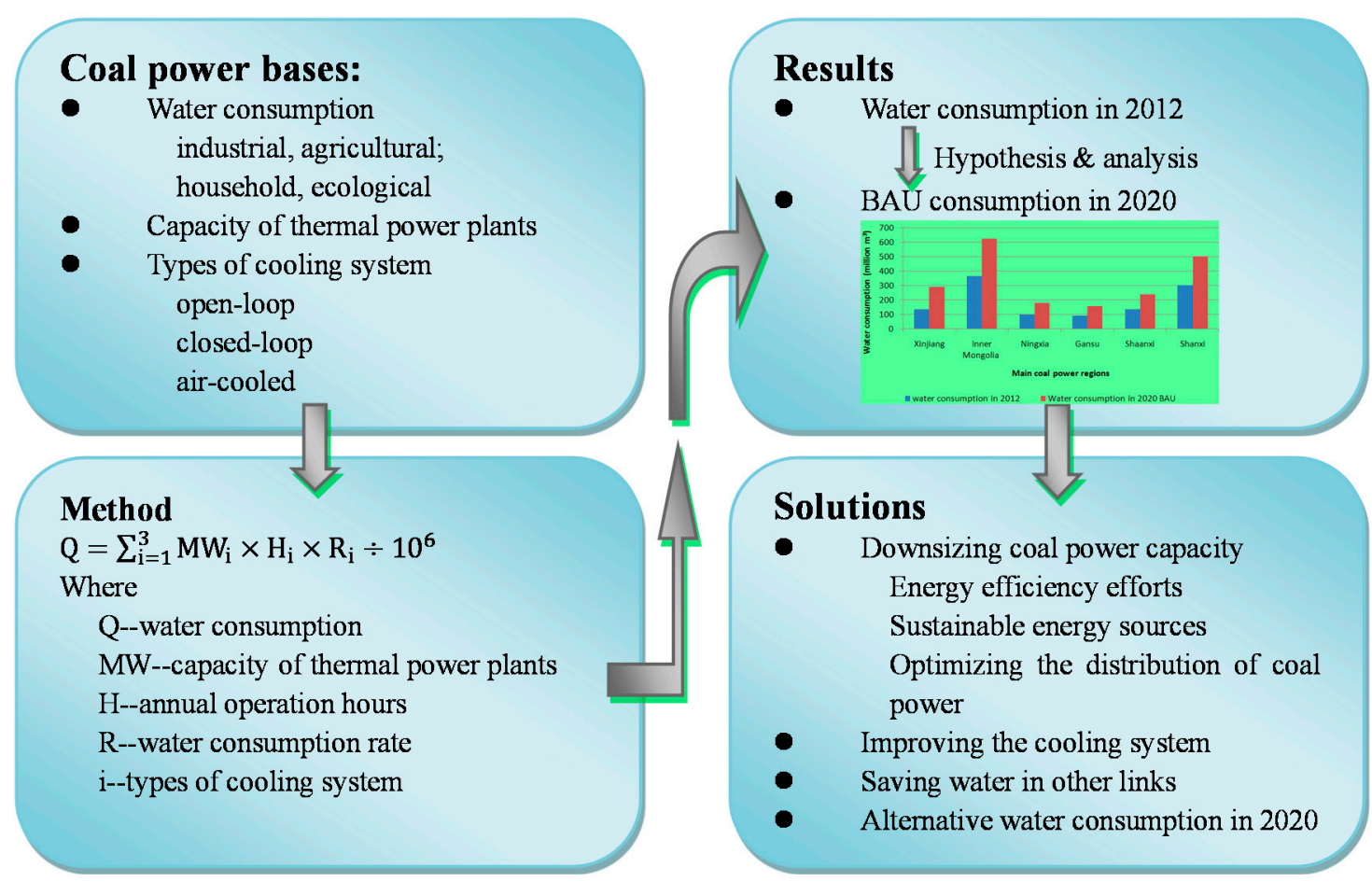

\section{Results}

\subsection{Current Water Consumption Status}

Annual Development Report on China's power industry 2013 by CEC has counted the whole-diameter capacity in every province by the end of 2012 [2]. According to this report, by the end of 2012, the installed coal power capacity is 50,110 MW in Shanxi, 60,190 MW in Inner Mongolia, 22,270 MW in Shaanxi, 22,570 MW in Xinjiang; 16,400 MW in Ningxia and 15,510 MW in Gansu.

According to the 2012 basic information and scoring statistics on nationwide $600 \mathrm{MW}$ thermal power units announced by CEC in 2013, we can estimate the distribution of cooling systems in these coal power provinces. There are approximately $75 \%$ of units adopting air-cooled system and other $25 \%$ of units adopting closed-loop cooling system, as shown in Table 3. Open-loop system, constrained by resource endowment in these western regions, is rarely deployed. According to Equation (1), we can estimate the water consumption by thermal power plants in these provinces, and the results are shown in Table 4. 
Table 3. Statistics on different cooling systems in China's coal power base provinces.

\begin{tabular}{cccc}
\hline \multirow{2}{*}{ Region } & \multicolumn{3}{c}{ Count of different cooling system } \\
\cline { 2 - 4 } & Open-loop & Closed-loop & Air-cooled \\
\hline Shanxi & 0 & 4 & 18 \\
Inner Mongolia & 2 & 12 & 20 \\
Shaanxi & 0 & 2 & 13 \\
Gansu & 0 & 0 & 2 \\
Ningxia & 0 & 0 & 8 \\
Total & 2 & 18 & 61 \\
\hline
\end{tabular}

Table 4. Water consumption by thermal power plants in coal power base provinces, 2012.

\begin{tabular}{|c|c|c|c|c|c|c|}
\hline Province & $\begin{array}{l}\text { Coal power } \\
\text { capacity/ } \\
\text { MW }\end{array}$ & $\begin{array}{l}\text { Types of } \\
\text { cooling } \\
\text { system }\end{array}$ & $\begin{array}{c}\text { Water } \\
\text { consumption } \\
\text { rate }\left(\mathbf{m}^{3} / \mathbf{M W h}\right)\end{array}$ & $\begin{array}{l}\text { Installed } \\
\text { capacity } \\
/ \mathrm{MW}\end{array}$ & $\begin{array}{c}\text { Water } \\
\text { consumption } \\
\left(1^{6} \mathrm{~m}^{3} / \mathbf{a}\right)\end{array}$ & $\begin{array}{c}\text { Total water } \\
\text { consumption } \\
\left(10^{6} \mathrm{~m}^{3} / \mathbf{a}\right)\end{array}$ \\
\hline \multirow{2}{*}{ Xinjiang } & \multirow{2}{*}{22,570} & Closed-loop & 1.83 & 5640 & 90.414 & \multirow{2}{*}{136.389} \\
\hline & & Air-cooled & 0.31 & 16,930 & 45.975 & \\
\hline \multirow{2}{*}{$\begin{array}{c}\text { Inner } \\
\text { Mongolia }\end{array}$} & \multirow{2}{*}{60,190} & Closed-loop & 1.83 & 15,050 & 241.264 & \multirow{2}{*}{363.846} \\
\hline & & Air-cooled & 0.31 & 45,140 & 122.582 & \\
\hline \multirow{2}{*}{ Ningxia } & \multirow{2}{*}{16,400} & Closed-loop & 1.83 & 4100 & 65.726 & \multirow{2}{*}{99.128} \\
\hline & & Air-cooled & 0.31 & 12,300 & 33.402 & \\
\hline \multirow{2}{*}{ Gansu } & \multirow{2}{*}{15,510} & Closed-loop & 1.83 & 3870 & 62.039 & \multirow{2}{*}{93.649} \\
\hline & & Air-cooled & 0.31 & 11,640 & 31.610 & \\
\hline \multirow{2}{*}{ Shaanxi } & \multirow{2}{*}{22,270} & Closed-loop & 1.83 & 5570 & 89.292 & \multirow{2}{*}{134.642} \\
\hline & & Air-cooled & 0.31 & 16,700 & 45.351 & \\
\hline \multirow{2}{*}{ Shanxi } & \multirow{2}{*}{50,110} & Closed-loop & 1.83 & 12,530 & 200.866 & \multirow{2}{*}{302.918} \\
\hline & & Air-cooled & 0.31 & 37,580 & 102.052 & \\
\hline Aggregate & 187,050 & & & & 1130.572 & 1130.572 \\
\hline
\end{tabular}

Then according to the statistical data on industrial water consumption, we can estimate the proportion of thermal power generation in the overall industrial water use in these provinces. The results are shown in Figure 4.

It is found that in both Ningxia and Shanxi provinces, coal power accounts for as high as $20 \%$ of industrial water consumption. For Inner Mongolia, coal power consumes $15 \%$ of the industrial water use. For Xinjiang and Shaanxi provinces, the percent is $10 \%$. Only in Gansu province the percentage is less than $10 \%$. Because of the scarcity of water resource in these provinces, we assume that further increase in industrial water supply is impossible or is much likely to bring conflicts between industrial water use and other purposes (ecological use or household use, for example) [18]. Therefore, we assume that further big increase in coal power/industrial water use percent is definitely unacceptable in the perspective of sustainable development in these provinces. 
Figure 4. Coal power vs. industrial water use in the coal power base provinces, 2012.

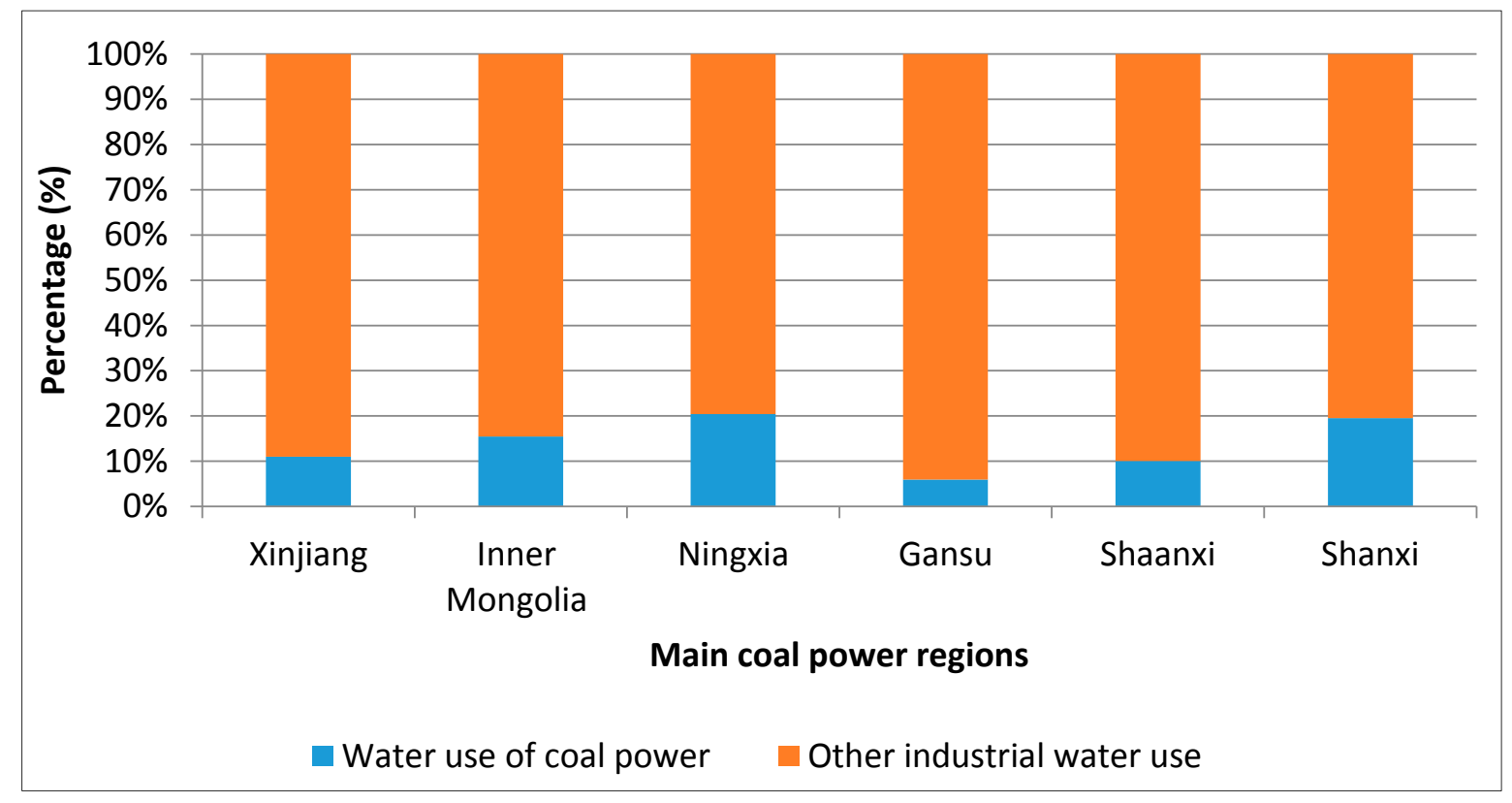

\subsection{BAU Water Consumption Scenario in 2020}

According to the "Power Development Strategic Research Report 2013" by CEC, the capacity of China's coal power plants in 2020 is expected to reach $1100 \mathrm{GW}$, and coal power bases will account for $55 \%$ of total newly-constructed plants. The BAU power demand and power planning is shown in Table 5.

Table 5. BAU (business-as-usual) power demand and power planning.

\begin{tabular}{ccc}
\hline & Capacity $(\mathbf{G W})$ & Electricity production (TWh) \\
\hline Hydropower & 360 & 1260 \\
Pumped storage & 60 & 48 \\
Coal power & 1050 & 5250 \\
Gas power & 100 & 300 \\
Nuclear power & 58 & 406 \\
Wind power & 200 & 400 \\
Solar power & 70 & 112 \\
Biomass energy & 15 & 67.5 \\
Total & 1913 & 7795.5 \\
Balancing loss & - & 90.5 \\
Electricity demand & - & 7705 \\
\hline
\end{tabular}

Assume constant water consumption rates, we can estimate the business-as-usual (BAU) scenario of water consumption by coal power plants in these coal power base provinces in 2020 (Table 6). According to the BAU scenario, it is estimated that water consumption for coal power generation will double during 2012-2020, provided that the comprehensive water consumption rates and the composition of cooling system are unchanged (Figure 5). It is worthwhile pointing out that all these coal power bases are puzzled by water shortage, and a double growth in water demand will certainly break the balance of water ecology system in these regions. 
Table 6. BAU Water consumption by thermal power plants in coal power base provinces, 2020.

\begin{tabular}{|c|c|c|c|c|c|c|}
\hline Province & $\begin{array}{c}\text { Total } \\
\text { capacity } \\
\text { /MW } \\
\end{array}$ & $\begin{array}{l}\text { Types of } \\
\text { cooling } \\
\text { system } \\
\end{array}$ & $\begin{array}{c}\text { Water } \\
\text { consumption } \\
\text { rate }\left(\mathbf{m}^{3} / \mathbf{M W h}\right)\end{array}$ & $\begin{array}{c}\text { Installed } \\
\text { capacity } \\
/ \mathrm{MW} \\
\end{array}$ & $\begin{array}{c}\text { Water } \\
\text { consumption } \\
\left(10^{6} \mathrm{~m}^{3} / \mathbf{a}\right) \\
\end{array}$ & $\begin{array}{c}\text { Total water } \\
\text { consumption } \\
\left(10^{6} \mathrm{~m}^{3} / \mathbf{a}\right)\end{array}$ \\
\hline \multirow{2}{*}{ Xinjiang } & \multirow{2}{*}{47,970} & Closed-loop & 1.83 & 11,990 & 192.209 & \multirow{2}{*}{289.917} \\
\hline & & Air-cooled & 0.31 & 35,980 & 97.707 & \\
\hline \multirow{2}{*}{$\begin{array}{c}\text { Inner } \\
\text { Mongolia }\end{array}$} & \multirow{2}{*}{102,900} & Closed-loop & 1.83 & 25,730 & 412.472 & \multirow{2}{*}{622.035} \\
\hline & & Air-cooled & 0.31 & 77,170 & 209.563 & \\
\hline \multirow{2}{*}{ Ningxia } & \multirow{2}{*}{29,670} & Closed-loop & 1.83 & 7420 & 118.949 & \multirow{2}{*}{179.371} \\
\hline & & Air-cooled & 0.31 & 22,250 & 60.422 & \\
\hline \multirow{2}{*}{ Gansu } & \multirow{2}{*}{26,300} & Closed-loop & 1.83 & 6580 & 105.483 & \multirow{2}{*}{159.034} \\
\hline & & Air-cooled & 0.31 & 19,720 & 53.552 & \\
\hline \multirow{2}{*}{ Shaanxi } & \multirow{2}{*}{39,520} & Closed-loop & 1.83 & 9880 & 158.384 & \multirow{2}{*}{238.875} \\
\hline & & Air-cooled & 0.31 & 29,640 & 80.490 & \\
\hline \multirow{2}{*}{ Shanxi } & \multirow{2}{*}{82,950} & Closed-loop & 1.83 & 20,740 & 332.479 & \multirow{2}{*}{501.416} \\
\hline & & Air-cooled & 0.31 & 62,210 & 168.937 & \\
\hline Total & 329,310 & & & 329,310 & 1990.648 & 1990.648 \\
\hline
\end{tabular}

Figure 5. 2020 BAU vs. 2012 water consumption by coal power in coal power base provinces.

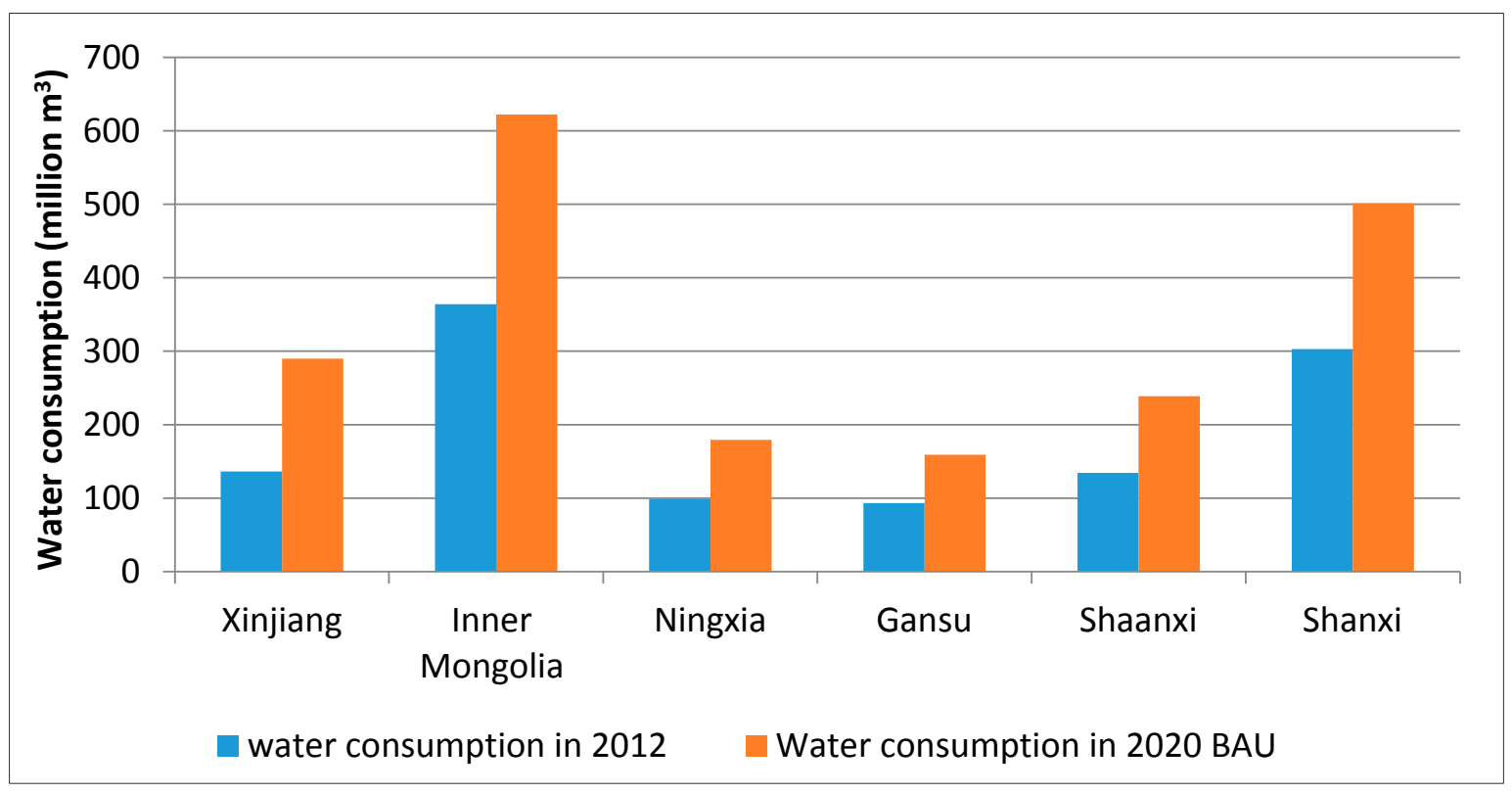

Furthermore, current water consumption by the power generation is substantial in volume and critical to its operation, but pressures of population growth, hydrological variability and climate change will complicate the issue. Water consumption in these provinces is always constrained by available supply and consumption in other industries is relative stable in the past. Hence, we hypothesize that water consumption in other industrial sectors will hold constant during 2012-2020, and then we can update the percentage of coal power/industrial water use for these provinces in 2020 (Figure 6). According to the estimate, with the exception of Gansu province, in the other five provinces, the percentages of coal power/industrial water use will be largely enlarged. In Shanxi and Ningxia provinces, coal power is expected to consume $30 \%$ of industrial water use in the BAU scenario; while in Xinjiang, Inner Mongolia 
and Shaanxi, coal power is expected to consume around $20 \%$ of industrial water use. In other words, the BAU scenario envisions higher possibility of water resource conflicts in these provinces.

Figure 6. Percentage of coal power/industrial water use in the BUA scenario.

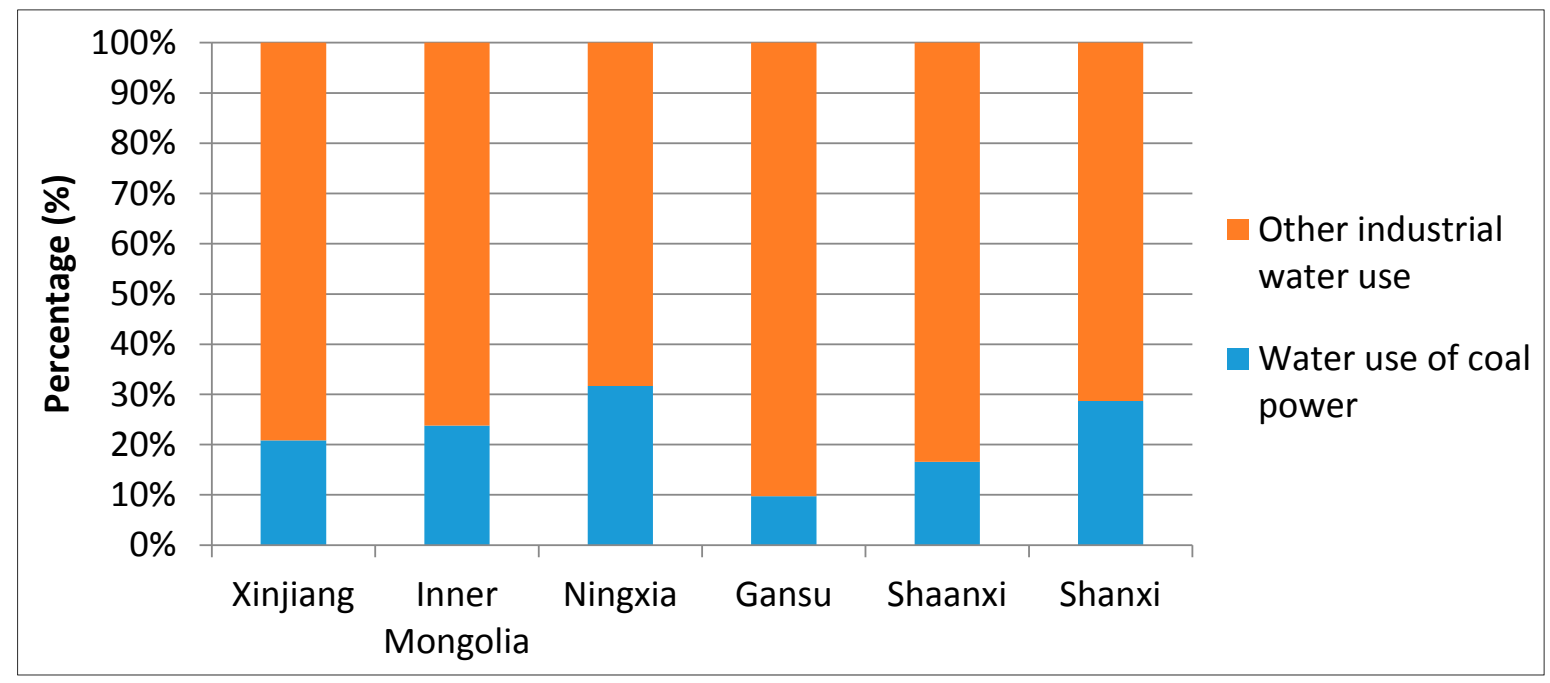

\section{Water Conservation Measures and Alternative Scenario}

Our projected result in these provinces has clearly indicated that serious water crisis will be likely to erupt in the BAU scenario. A strong implication is that the Chinese Government must take water resource constraint into consideration as a critical point in its overall sustainable development plan, in addition to energy supply and environment protection. The point is that an integrated energy-water resource plan with regionalized environmental carrying capacity as constraints is a desideratum to settle this puzzle. Hence, in this section, firstly possible measures to cut down (or avoid) water consumption will be discussed. Then, an alternative scenario will be proposed to guide the sustainable energy development in these coal power base provinces.

\subsection{Water Conservation Measures}

\subsubsection{Downsizing Coal Power Capacity}

The most effective measure to cope with water resource crisis caused by power generation is cutting down the scale of coal power capacity in western provinces. In other words, an alternative power plan is needed. The following strategies can be employed in developing the power sector plan:

- Reducing electric power demand by active energy efficiency efforts. Energy efficiency has been regarded as the fifth energy source besides coal, oil, gas and hydropower. Worldwide experience has also clearly demonstrated the efficacy of energy efficiency in optimizing energy system. We estimate that with active energy efficiency efforts, the demand growth for electric power can be slowed down by $2 \%-3 \%$ and results in energy conservation at 200-300 TWh annually. The energy efficiency potential into 2020 by various active efforts is shown in Table 7. 
Table 7. The energy efficiency potential of active efforts into 2020.

\begin{tabular}{cc}
\hline Technology/sector & Energy efficiency potential (TWh) \\
\hline Green lighting & 108.51 \\
High efficiency motor & 130.00 \\
Energy-saving transformer & 8.87 \\
Frequency converter & 97.70 \\
High efficiency appliance & 442.00 \\
Ground source heat pump technology & 18.00 \\
\hline Total & 805.08
\end{tabular}

- Optimizing generation mix by deploying clean and sustainable energy sources. On one hand, in China the hydropower development is yet to reach its economically developable resource limit. On the other hand, China is endowed with abundant renewable energy sources like wind power and solar power, and active support of renewable energy development can make a big difference.

- Optimizing the regional distribution of coal power. With the development of zero emission technology, coal power can generate electricity at emission levels ( $\mathrm{SO}_{2}, \mathrm{NOx}$ and dust) closer to or even lower than gas power [40]. Hence, the government can lift the ban on the new construction of coal power plants in east regions and plan to build some coal power plants with cutting-edge pollutant control technologies in the load centers. The benefits are twofold. First, China's potential water resource crisis in western can be partly relieved. Second, the demand on long-distance electric power transmission - another important concern of decision-makers — can also be reduced.

\subsubsection{Saving Water by Improving the Cooling System}

The cooling system consumes most of water in the power generation process. Therefore, another priority of water conservation is to improve the cooling system in coal power plants. In the existing coal power fleet, these plants with advanced closed-loop water cooling system perform as effectively as those with air-cooled system in terms of the comprehensive water consumption rate while enjoying super energy efficiency advantage. Here, an important measure is to raise the technical threshold of new coal power plants and require that all the newly-constructed coal power plants perform better in their water consumption than the existing records. For existing plants, technical retrofitting can be implemented in those plants with below than average water efficiency performance.

\subsubsection{Saving Water in Other Links}

The demand on water quality in the other links of power plants is not as strict as in the cooling system. For example, treated wastewater, instead of fresh water, can be used in the desulfurization system and the coal yard. Use of nontraditional water sources, such as secondary-treated municipal wastewater, provides an option to reduce freshwater usage in thermal power production [41]. In the subsequent subsection, concrete water conservation measures are proposed from many links in the generation process. 
- Ash and slag removal system: Dry-type ash and slag removal system, which consumes no water at all, is a mature option. On the other hand, with this process, the produced ash and slag can be reclaimed as building material [41].

- Cooling system of auxiliary systems: The cooling water for the auxiliary systems can be processed in a centralized way. Similarly, a small-scale wet recirculating or dry recirculating cooling system can be employed for the cooling of the pooled water.

- Desulfurization system: Dry desulfurization process consumes much less water than wet process. For the wet desulfurization process, the cyclic utilization of processing water is a feasible option. Other option is to use the reclaimed water in the cooling system for the auxiliary systems in desulfurization process.

- Water use of coal yard: The water quality demand in the coal yard is much lower. Retreated industrial wastewater or domestic wastewater can be collected for this purpose. Besides, the wastewater produced in coal yard can also be reutilized to further cut down water consumption.

\subsection{An Alternative Water Consumption Scenario}

In the alternative water consumption scenario, with energy efficiency efforts, electricity demand is projected to drop from 7705.5 TWh to $7560 \mathrm{TWh}$. In addition, with more clean and sustainable energy sources, the demand for thermal power is reduced by almost $100 \mathrm{GW}$, as shown in Table 8 .

Table 8. Alternative power demand and power planning.

\begin{tabular}{ccc}
\hline & Capacity $(\mathbf{G W})$ & Power production (TWh) \\
\hline Hydropower & 360 & 1260 \\
Pumped storage & 70 & 56 \\
Coal power & 959.91 & 4799.6 \\
Gas power-centralized & 70 & 350 \\
Gas power-distributed & 50 & 125 \\
Nuclear power & 60 & 420 \\
Wind power & 230 & 460 \\
Solar power-centralized & 40 & 64 \\
Solar power-distributed & 60 & 72 \\
Biomass energy & 14 & 63 \\
Total & 1913.91 & 7594.9 \\
Balancing loss & - & 34.9 \\
Electricity demand & - & 7560 \\
\hline
\end{tabular}

Due to technological advances and structural optimization, the comprehensive water consumption rate could be cut down by a large extent in the alternative scenario. Our estimate is that the water consumption rate could be cut down by $30 \%$ from the existing level. In addition, we project that more air-cooled units would be built. The details of the alternative scenario are reported in Table 9. 
Table 9. Alternative water consumption in coal power base provinces.

\begin{tabular}{|c|c|c|c|c|c|c|}
\hline Province & $\begin{array}{c}\text { Total } \\
\text { capacity } \\
\text { /MW } \\
\end{array}$ & $\begin{array}{l}\text { Types of } \\
\text { cooling } \\
\text { system } \\
\end{array}$ & $\begin{array}{c}\text { Water } \\
\text { consumption } \\
\text { rate }\left(\mathbf{m}^{3} / \mathbf{M W h}\right)\end{array}$ & $\begin{array}{c}\text { Installed } \\
\text { capacity } \\
/ \mathrm{MW} \\
\end{array}$ & $\begin{array}{c}\text { Water } \\
\text { consumption } \\
\left(10^{6} \mathrm{~m}^{3} / \mathbf{a}\right) \\
\end{array}$ & $\begin{array}{c}\text { Total water } \\
\text { consumption } \\
\left(1^{6} \mathbf{m}^{3} / \mathbf{a}\right) \\
\end{array}$ \\
\hline \multirow{2}{*}{ Xinjiang } & \multirow{2}{*}{45,050} & Closed-loop & 1.27 & 9010 & 100.238 & \multirow{2}{*}{172.851} \\
\hline & & Air-cooled & 0.23 & 36,040 & 72.613 & \\
\hline \multirow{2}{*}{$\begin{array}{c}\text { Inner } \\
\text { Mongolia }\end{array}$} & \multirow{2}{*}{100,000} & Closed-loop & 1.27 & 20,000 & 222.504 & \multirow{2}{*}{383.688} \\
\hline & & Air-cooled & 0.23 & 80,000 & 161.184 & \\
\hline \multirow{2}{*}{ Ningxia } & \multirow{2}{*}{27,580} & Closed-loop & 1.27 & 5520 & 61.411 & \multirow{2}{*}{105.858} \\
\hline & & Air-cooled & 0.23 & 22,060 & 44.446 & \\
\hline \multirow{2}{*}{ Gansu } & \multirow{2}{*}{24,390} & Closed-loop & 1.27 & 4880 & 54.291 & \multirow{2}{*}{93.600} \\
\hline & & Air-cooled & 0.23 & 19,510 & 39.309 & \\
\hline \multirow{2}{*}{ Shaanxi } & \multirow{2}{*}{38,140} & Closed-loop & 1.27 & 7630 & 84.885 & \multirow{2}{*}{146.357} \\
\hline & & Air-cooled & 0.23 & 30,510 & 61.472 & \\
\hline \multirow{2}{*}{ Shanxi } & \multirow{2}{*}{80,950} & Closed-loop & 1.27 & 16,190 & 180.117 & \multirow{2}{*}{310.595} \\
\hline & & Air-cooled & 0.23 & 64,760 & 130.478 & \\
\hline Aggregate & 316,110 & & & 316,110 & 1212.949 & 1212.949 \\
\hline
\end{tabular}

In the alternative scenario, planned coal-fired generation capacity in these provinces would be $13 \mathrm{GW}$ lower than in the BAU scenario. Also, the comprehensive water consumption rate of the closed-loop cooling system would be lowered to $1.27 \mathrm{~m}^{3} / \mathrm{MWh}$. The water consumption by coal power in these provinces will be 1212 million $\mathrm{m}^{3}$, with only a slight increase relative to 2012 level. In this way, the envisioned water crisis caused by the electric power industry in these water-deprived provinces could possibly be avoided. However, we should not be too optimistic about it. Great risk exists in the implementation of water conservation measures and their actual effects.

\section{Concluding Remarks}

Coal power is an inevitable choice for meeting the increasing electric power demand in China. Considering the ever worsening atmospheric pollution, the Chinese Government has to adhere to the path of developing large-scale coal power bases in western provinces. However, the analysis presented in this paper clearly indicates that there will be furious water-energy conflicts in the development of coal bases, and water resource constraints will seriously restrict their development. An integrated planning of energy and water resources which takes regionalized environmental carrying capacity as the constraint is a final resort to this sustainable development puzzle. Several concrete water conservation measures are proposed to address the water crisis in China's coal power bases.

Certainly, our study is suffering from some limitations. For example, the perspective employed in the study is water resource constraint. Other important factors, such as the deployment cost of new cooling system and the retrofitting cost of existing cooling system, the economic appraisal of water conservation in links other than cooling system, are not addressed in the study. Water issue is only projected to worsen in the future, as a consequence of climate change. Therefore, further and more in-depth analysis on the issues presented here is needed to provide guidance for Chinese government and other stakeholders. 


\section{Acknowledgments}

The authors would like to thank the anonymous reviewers for their useful comments and suggestions. The work reported in the paper is funded by Beijing Higher Education Young Elite Teacher Project (YETP0707) and the Fundamental Research Funds for the Central Universities.

\section{Author Contributions}

Jiahai Yuan contributed to the research idea and the framework of this study. Other authors contributed equally to the study.

\section{Appendix}

Table A1. Energy efficiency and water efficiency statistics on coal-fired power plants in China, 2012.

\begin{tabular}{|c|c|c|c|c|}
\hline $\begin{array}{c}\text { Plant } \\
\text { No. }\end{array}$ & $\begin{array}{l}\text { Capacity } \\
\text { (MW) }\end{array}$ & $\begin{array}{c}\text { Comprehensive water } \\
\text { consumption rate }\left(\mathrm{m}^{3} / \mathbf{M W h}\right)\end{array}$ & $\begin{array}{c}\text { Types of cooling } \\
\text { system }\end{array}$ & $\begin{array}{l}\text { Heat rates } \\
\text { (gce/kWh) }\end{array}$ \\
\hline 1 & 640 & 1.91 & Closed-loop & 298.29 \\
\hline 2 & 640 & 2.10 & Closed-loop & 297.71 \\
\hline 3 & 1000 & 0.30 & Open-loop & 275.85 \\
\hline 4 & 630 & 1.31 & Closed-loop & 296.2 \\
\hline 5 & 640 & 1.98 & Closed-loop & 297.85 \\
\hline 6 & 630 & 0.35 & Open-loop & 296.77 \\
\hline 7 & 640 & 1.99 & Closed-loop & 298.36 \\
\hline 8 & 600 & 0.23 & Open-loop & 306.28 \\
\hline 9 & 630 & 1.31 & Closed-loop & 297.33 \\
\hline 10 & 640 & 1.92 & Closed-loop & 298.15 \\
\hline 11 & 1000 & 0.30 & Open-loop & 276.44 \\
\hline 12 & 630 & 2.20 & Closed-loop & 296.78 \\
\hline 13 & 600 & 0.23 & Open-loop & 308.21 \\
\hline 14 & 500 & 1.83 & Closed-loop & 306.05 \\
\hline 15 & 600 & 2.00 & Closed-loop & 307.3 \\
\hline 16 & 660 & 0.25 & Air-cooled & 310.21 \\
\hline 17 & 600 & 0.29 & Open-loop & 298.97 \\
\hline 18 & 500 & 1.60 & Closed-loop & 324.06 \\
\hline 19 & 700 & 2.10 & Closed-loop & 307.61 \\
\hline 20 & 600 & 2.00 & Closed-loop & 309.35 \\
\hline 21 & 600 & 0.24 & Air-cooled & 326.41 \\
\hline 22 & 600 & 1.72 & Closed-loop & 302.35 \\
\hline 23 & 600 & 2.00 & Closed-loop & 298.51 \\
\hline 24 & 600 & 1.70 & Closed-loop & 302.12 \\
\hline 25 & 600 & 0.24 & Air-cooled & 326.7 \\
\hline 26 & 600 & 1.57 & Closed-loop & 310.03 \\
\hline 27 & 1000 & 0.23 & Closed-loop & 287.18 \\
\hline 28 & 1000 & 0.10 & Open-loop & 282. \\
\hline 29 & 600 & 0.23 & Air-cooled & 330.13 \\
\hline
\end{tabular}


Table A1. Cont.

\begin{tabular}{|c|c|c|c|c|}
\hline $\begin{array}{l}\text { Plant } \\
\text { No. }\end{array}$ & $\begin{array}{l}\text { Capacity } \\
\text { (MW) }\end{array}$ & $\begin{array}{c}\text { Comprehensive water } \\
\text { consumption rate }\left(\mathrm{m}^{3} / \mathbf{M W h}\right)\end{array}$ & $\begin{array}{c}\text { Types of cooling } \\
\text { system }\end{array}$ & $\begin{array}{l}\text { Heat rates } \\
\text { (gce/kWh) }\end{array}$ \\
\hline 30 & 600 & 0.47 & Air-cooled & 318.14 \\
\hline 31 & 600 & 0.25 & Open-loop & 310.5 \\
\hline 32 & 600 & 0.23 & Air-cooled & 330.05 \\
\hline 33 & 900 & 0.43 & Open-loop & 299.82 \\
\hline 34 & 500 & 1.83 & Closed-loop & 306.28 \\
\hline 35 & 630 & 1.47 & Closed-loop & 300.58 \\
\hline 36 & 630 & 0.35 & Open-loop & 298.53 \\
\hline 37 & 600 & 0.24 & Air-cooled & 327.53 \\
\hline 38 & 630 & 0.35 & Open-loop & 300.3 \\
\hline 39 & 600 & 0.33 & Air-cooled & 329.62 \\
\hline 40 & 660 & 0.32 & Open-loop & 288.2 \\
\hline 41 & 660 & 1.73 & Closed-loop & 298.01 \\
\hline 42 & 630 & 1.99 & Closed-loop & 305.3 \\
\hline 43 & 700 & 2.10 & Closed-loop & 311.39 \\
\hline 44 & 600 & 2.83 & Closed-loop & 310.97 \\
\hline 45 & 660 & 0.19 & Air-cooled & 323.55 \\
\hline 46 & 660 & 0.43 & Open-loop & 291.51 \\
\hline 47 & 670 & 2.07 & Closed-loop & 301.11 \\
\hline 48 & 640 & 1.88 & Closed-loop & 305.12 \\
\hline 49 & 670 & 2.07 & Closed-loop & 302.07 \\
\hline 50 & 600 & 0.26 & Air-cooled & 328.14 \\
\hline 51 & 680 & 0.19 & Open-loop & 298.6 \\
\hline 52 & 600 & 0.26 & Air-cooled & 327.11 \\
\hline 53 & 660 & 1.31 & Closed-loop & 291.34 \\
\hline 54 & 600 & 1.90 & Closed-loop & 307.57 \\
\hline 55 & 600 & 1.87 & Closed-loop & 302.45 \\
\hline 56 & 680 & 0.11 & Open-loop & 289.98 \\
\hline 57 & 600 & 0.24 & Air-cooled & 331.9 \\
\hline 58 & 630 & 1.85 & Closed-loop & 301.08 \\
\hline 59 & 1000 & 2.01 & Closed-loop & 285.71 \\
\hline 60 & 600 & 2.10 & Closed-loop & 315.48 \\
\hline 61 & 1000 & 2.01 & Closed-loop & 286.11 \\
\hline 62 & 660 & 0.41 & Open-loop & 311.3 \\
\hline 63 & 600 & 2.03 & Closed-loop & 301.49 \\
\hline 64 & 630 & 0.42 & Air-cooled & 323.42 \\
\hline 65 & 600 & 0.24 & Open-loop & 311.66 \\
\hline 66 & 630 & 0.42 & Air-cooled & 323.39 \\
\hline 67 & 600 & 2.81 & Closed-loop & 319.58 \\
\hline 68 & 600 & 1.85 & Closed-loop & 300.86 \\
\hline 69 & 1000 & 0.26 & Open-loop & 285.58 \\
\hline 70 & 630 & 2.26 & Closed-loop & 304.13 \\
\hline 71 & 600 & 0.34 & Open-loop & 300.71 \\
\hline 72 & 660 & 0.43 & Open-loop & 291.51 \\
\hline
\end{tabular}


Table A1. Cont.

\begin{tabular}{|c|c|c|c|c|}
\hline $\begin{array}{l}\text { Plant } \\
\text { No. }\end{array}$ & $\begin{array}{l}\text { Capacity } \\
\text { (MW) }\end{array}$ & $\begin{array}{c}\text { Comprehensive water } \\
\text { consumption rate }\left(\mathbf{m}^{3} / \mathbf{M W h}\right)\end{array}$ & $\begin{array}{c}\text { Types of cooling } \\
\text { system }\end{array}$ & $\begin{array}{l}\text { Heat rates } \\
\text { (gce/kWh) }\end{array}$ \\
\hline 73 & 600 & 0.29 & Open-loop & 312.11 \\
\hline 74 & 600 & 0.24 & Open-loop & 299.99 \\
\hline 75 & 600 & 0.20 & Open-loop & 310.03 \\
\hline 76 & 900 & 0.43 & Open-loop & 301.01 \\
\hline 77 & 1000 & 0.27 & Open-loop & 285.55 \\
\hline 78 & 600 & 0.24 & Air-cooled & 330.73 \\
\hline 79 & 650 & 0.33 & Closed-loop & 303.07 \\
\hline 80 & 660 & 0.17 & Open-loop & 294.85 \\
\hline 81 & 600 & 2.46 & Closed-loop & 304.26 \\
\hline 82 & 630 & 1.99 & Closed-loop & 306.8 \\
\hline 83 & 600 & 0.41 & Air-cooled & 330.38 \\
\hline 84 & 600 & 2.83 & Closed-loop & 311.91 \\
\hline 85 & 600 & 0.29 & Open-loop & 313.48 \\
\hline 86 & 600 & 0.24 & Open-loop & 301.48 \\
\hline 87 & 600 & 0.24 & Air-cooled & 331.15 \\
\hline 88 & 600 & 2.46 & Closed-loop & 304.87 \\
\hline 89 & 600 & 1.78 & Closed-loop & 302.49 \\
\hline 90 & 600 & 1.57 & Closed-loop & 314.35 \\
\hline 91 & 660 & 1.62 & Closed-loop & 297.16 \\
\hline 92 & 600 & 1.85 & Closed-loop & 308.1 \\
\hline 93 & 1000 & 1.65 & Closed-loop & 288.77 \\
\hline 94 & 630 & 2.20 & Closed-loop & 301.75 \\
\hline 95 & 600 & 1.75 & Closed-loop & 315.73 \\
\hline 96 & 660 & 0.19 & Air-cooled & 323.41 \\
\hline 97 & 630 & 0.41 & Open-loop & 302.36 \\
\hline 98 & 600 & 0.49 & Air-cooled & 320.25 \\
\hline 99 & 650 & 0.28 & Open-loop & 302.93 \\
\hline 100 & 600 & 0.24 & Open-loop & 300.39 \\
\hline 101 & 600 & 1.76 & Closed-loop & 306.17 \\
\hline 102 & 600 & 0.20 & Open-loop & 313.97 \\
\hline 103 & 600 & 2.01 & Closed-loop & 305.2 \\
\hline 104 & 600 & 1.95 & Closed-loop & 320.04 \\
\hline 105 & 1000 & 0.31 & Air-cooled & 306.9 \\
\hline 106 & 600 & 1.57 & Closed-loop & 314.62 \\
\hline 107 & 600 & 0.29 & Open-loop & 302.52 \\
\hline 108 & 630 & 1.97 & Closed-loop & 303.66 \\
\hline 109 & 600 & 2.90 & Closed-loop & 319.42 \\
\hline 110 & 600 & 1.57 & Closed-loop & 314.97 \\
\hline 111 & 1000 & 0.32 & Open-loop & 283.93 \\
\hline 112 & 660 & 0.41 & Open-loop & 315.05 \\
\hline 113 & 1000 & 0.81 & Closed-loop & 285. \\
\hline 114 & 600 & 1.75 & Closed-loop & 316.69 \\
\hline 115 & 600 & 0.19 & Open-loop & 313.92 \\
\hline
\end{tabular}


Table A1. Cont.

\begin{tabular}{|c|c|c|c|c|}
\hline $\begin{array}{l}\text { Plant } \\
\text { No. }\end{array}$ & $\begin{array}{l}\text { Capacity } \\
\text { (MW) }\end{array}$ & $\begin{array}{c}\text { Comprehensive water } \\
\text { consumption rate }\left(\mathrm{m}^{3} / \mathbf{M W h}\right)\end{array}$ & $\begin{array}{c}\text { Types of cooling } \\
\text { system }\end{array}$ & $\begin{array}{l}\text { Heat rates } \\
\text { (gce/kWh) }\end{array}$ \\
\hline 116 & 600 & 1.76 & Closed-loop & 306.39 \\
\hline 117 & 600 & 0.24 & Open-loop & 301.66 \\
\hline 118 & 600 & 2.05 & Closed-loop & 318. \\
\hline 119 & 660 & 0.32 & Open-loop & 293.12 \\
\hline 120 & 640 & 2.10 & Closed-loop & 302.07 \\
\hline 121 & 600 & 2.03 & Closed-loop & 303.19 \\
\hline 122 & 660 & 0.36 & Air-cooled & 314.82 \\
\hline 123 & 600 & 1.76 & Closed-loop & 305.96 \\
\hline 124 & 1000 & 0.19 & Open-loop & 289.61 \\
\hline 125 & 600 & 1.83 & Closed-loop & 306.03 \\
\hline 126 & 660 & 0.26 & Open-loop & 298.98 \\
\hline 127 & 660 & 0.31 & Open-loop & 292.89 \\
\hline 128 & 600 & 0.36 & Open-loop & 305.13 \\
\hline 129 & 1000 & 0.23 & Closed-loop & 291.46 \\
\hline 130 & 600 & 0.41 & Air-cooled & 332.7 \\
\hline 131 & 600 & 2.46 & Closed-loop & 305.95 \\
\hline 132 & 600 & 0.27 & Air-cooled & 331.91 \\
\hline 133 & 630 & 0.35 & Open-loop & 303.38 \\
\hline 134 & 600 & 0.24 & Open-loop & 304.19 \\
\hline 135 & 600 & 1.75 & Closed-loop & 319.14 \\
\hline 136 & 630 & 0.14 & Open-loop & 306.29 \\
\hline 137 & 630 & 1.67 & Closed-loop & 305.48 \\
\hline 138 & 600 & 0.23 & Air-cooled & 337.29 \\
\hline 139 & 600 & 0.34 & Open-loop & 303.17 \\
\hline 140 & 600 & 2.46 & Closed-loop & 305.71 \\
\hline 141 & 680 & 0.19 & Open-loop & 303.58 \\
\hline 142 & 600 & 0.24 & Open-loop & 311.64 \\
\hline 143 & 660 & 0.18 & Open-loop & 298.47 \\
\hline 144 & 600 & 0.41 & Air-cooled & 333.87 \\
\hline 145 & 1000 & 0.16 & Open-loop & 286.6 \\
\hline 146 & 680 & 0.11 & Open-loop & 294.31 \\
\hline 147 & 600 & 2.00 & Closed-loop & 318.28 \\
\hline 148 & 600 & 1.80 & Closed-loop & 307.34 \\
\hline 149 & 600 & 0.29 & Closed-loop & 313.94 \\
\hline 150 & 650 & 0.33 & Closed-loop & 306.63 \\
\hline 151 & 600 & 0.24 & Open-loop & 304.92 \\
\hline 152 & 600 & 2.16 & Closed-loop & 311.51 \\
\hline 153 & 600 & 1.83 & Closed-loop & 305.74 \\
\hline 154 & 600 & 0.29 & Open-loop & 303.69 \\
\hline 155 & 1000 & 0.29 & Closed-loop & 290.67 \\
\hline 157 & 650 & 0.30 & Open-loop & 305.25 \\
\hline 158 & 660 & 1.03 & Closed-loop & 324. \\
\hline 159 & 660 & 0.28 & Open-loop & 292.09 \\
\hline
\end{tabular}


Table A1. Cont.

\begin{tabular}{|c|c|c|c|c|}
\hline $\begin{array}{l}\text { Plant } \\
\text { No. }\end{array}$ & $\begin{array}{l}\text { Capacity } \\
\text { (MW) }\end{array}$ & $\begin{array}{c}\text { Comprehensive water } \\
\text { consumption rate }\left(\mathbf{m}^{3} / \mathbf{M W h}\right)\end{array}$ & $\begin{array}{c}\text { Types of cooling } \\
\text { system }\end{array}$ & $\begin{array}{l}\text { Heat rates } \\
\text { (gce/kWh) }\end{array}$ \\
\hline 160 & 660 & 1.73 & Closed-loop & 302.49 \\
\hline 161 & 1000 & 0.16 & Open-loop & 288.99 \\
\hline 162 & 1000 & 1.65 & Closed-loop & 289.5 \\
\hline 163 & 1000 & 0.28 & Open-loop & 289.07 \\
\hline 164 & 600 & 1.60 & Closed-loop & 309.03 \\
\hline 165 & 600 & 2.03 & Closed-loop & 310.84 \\
\hline 166 & 660 & 2.05 & Closed-loop & 309.78 \\
\hline 167 & 630 & 0.34 & Open-loop & 308.04 \\
\hline 168 & 600 & 1.84 & Closed-loop & 307.46 \\
\hline 169 & 600 & 0.29 & Open-loop & 303.06 \\
\hline 170 & 600 & 1.76 & Closed-loop & 306.29 \\
\hline 171 & 660 & 0.24 & Open-loop & 299.56 \\
\hline 172 & 1000 & 0.28 & Open-loop & 285.09 \\
\hline 173 & 600 & 2.49 & Closed-loop & 309.85 \\
\hline 174 & 660 & 0.24 & Open-loop & 296.98 \\
\hline 175 & 600 & 0.39 & Air-cooled & 338.06 \\
\hline 176 & 660 & 0.02 & Open-loop & 294.52 \\
\hline 177 & 600 & 0.41 & Air-cooled & 334.8 \\
\hline 178 & 1000 & 0.28 & Open-loop & 289.2 \\
\hline 179 & 1000 & 0.89 & Closed-loop & 285.05 \\
\hline 180 & 660 & 2.05 & Closed-loop & 309.78 \\
\hline 181 & 630 & 0.34 & Open-loop & 316.79 \\
\hline 182 & 1000 & 0.31 & Air-cooled & 308.01 \\
\hline 183 & 1000 & 0.28 & Open-loop & 289.02 \\
\hline 184 & 600 & 0.36 & Open-loop & 309.38 \\
\hline 185 & 660 & 0.31 & Air-cooled & 320.86 \\
\hline 186 & 660 & 0.18 & Open-loop & 299.94 \\
\hline 187 & 600 & 2.00 & Closed-loop & 306.58 \\
\hline 188 & 630 & 0.43 & Open-loop & 312.91 \\
\hline 189 & 1000 & 0.40 & Open-loop & 289.51 \\
\hline 190 & 630 & 0.39 & Open-loop & 309.73 \\
\hline 191 & 500 & 1.60 & Closed-loop & 327.8 \\
\hline 192 & 600 & 0.23 & Air-cooled & 335.44 \\
\hline 193 & 600 & 0.24 & Open-loop & 304.24 \\
\hline 194 & 1000 & 0.19 & Open-loop & 291.34 \\
\hline 195 & 660 & 0.02 & Open-loop & 295.42 \\
\hline 196 & 600 & 0.31 & Air-cooled & 337.53 \\
\hline 197 & 600 & 0.27 & Open-loop & 309.85 \\
\hline 198 & 600 & 2.13 & Closed-loop & 321.41 \\
\hline 199 & 660 & 0.18 & Open-loop & 301.81 \\
\hline 200 & 1000 & 0.39 & Open-loop & 292.2 \\
\hline 201 & 660 & 1.03 & Closed-loop & 324.7 \\
\hline 202 & 600 & 1.75 & Closed-loop & 309.03 \\
\hline
\end{tabular}


Table A1. Cont.

\begin{tabular}{|c|c|c|c|c|}
\hline $\begin{array}{c}\text { Plant } \\
\text { No. }\end{array}$ & $\begin{array}{c}\text { Capacity } \\
\text { (MW) }\end{array}$ & $\begin{array}{c}\text { Comprehensive water } \\
\text { consumption rate }\left(\mathrm{m}^{3} / \mathbf{M W h}\right)\end{array}$ & $\begin{array}{c}\text { Types of cooling } \\
\text { system }\end{array}$ & $\begin{array}{l}\text { Heat rates } \\
(\text { gce/kWh) }\end{array}$ \\
\hline 204 & 660 & 1.65 & Closed-loop & 300.1 \\
\hline 205 & 600 & 2.13 & Closed-loop & 321.41 \\
\hline 206 & 600 & 1.84 & Closed-loop & 308.99 \\
\hline 207 & 660 & 0.17 & Open-loop & 306.56 \\
\hline 208 & 630 & 0.34 & Open-loop & 308.87 \\
\hline 209 & 600 & 2.20 & Closed-loop & 318.28 \\
\hline 210 & 1000 & 0.40 & Open-loop & 288.15 \\
\hline 211 & 660 & 0.41 & Open-loop & 314.32 \\
\hline 212 & 1000 & 0.21 & Open-loop & 284.56 \\
\hline 213 & 600 & 1.75 & Closed-loop & 320.92 \\
\hline 214 & 600 & 0.40 & Air-cooled & 330.38 \\
\hline 215 & 660 & 0.28 & Open-loop & 292.8 \\
\hline 216 & 660 & 0.31 & Air-cooled & 321.15 \\
\hline 217 & 650 & 0.32 & Open-loop & 307.82 \\
\hline 218 & 600 & 1.71 & Closed-loop & 320.74 \\
\hline 219 & 600 & 0.33 & Air-cooled & 338.41 \\
\hline 220 & 600 & 1.78 & Closed-loop & 307.04 \\
\hline 221 & 660 & 1.74 & Closed-loop & 305.11 \\
\hline 222 & 1000 & 0.32 & Open-loop & 293.25 \\
\hline 223 & 600 & 0.39 & Air-cooled & 338.4 \\
\hline 224 & 680 & 0.39 & Open-loop & 302.96 \\
\hline 225 & 660 & 0.28 & Open-loop & 302.73 \\
\hline 226 & 660 & 0.36 & Air-cooled & 328.9 \\
\hline 227 & 660 & 0.35 & Air-cooled & 333.58 \\
\hline 228 & 600 & 0.18 & Open-loop & 297.56 \\
\hline 229 & 660 & 0.31 & Air-cooled & 325.03 \\
\hline 230 & 600 & 2.07 & Closed-loop & 320.33 \\
\hline 231 & 630 & 2.26 & Closed-loop & 308.05 \\
\hline 232 & 600 & 2.07 & Closed-loop & 313.43 \\
\hline 233 & 660 & 0.31 & Air-cooled & 328.35 \\
\hline 234 & 630 & 0.63 & Open-loop & 306.7 \\
\hline 235 & 660 & 0.34 & Air-cooled & 329.91 \\
\hline 236 & 660 & 1.30 & Closed-loop & 291.34 \\
\hline 237 & 660 & 1.71 & Closed-loop & 305.72 \\
\hline 238 & 630 & 0.14 & Open-loop & 306.36 \\
\hline 239 & 600 & 1.96 & Closed-loop & 320.28 \\
\hline 240 & 600 & 0.31 & Air-cooled & 338.79 \\
\hline 241 & 600 & 2.02 & Closed-loop & 308.06 \\
\hline 242 & 630 & 0.41 & Open-loop & 303.68 \\
\hline 243 & 600 & 1.81 & Closed-loop & 313.89 \\
\hline 244 & 660 & 0.24 & Open-loop & 310.58 \\
\hline 245 & 600 & 3.83 & Closed-loop & 327.47 \\
\hline 246 & 600 & 0.27 & Air-cooled & 339.18 \\
\hline
\end{tabular}


Table A1. Cont.

\begin{tabular}{|c|c|c|c|c|}
\hline $\begin{array}{l}\text { Plant } \\
\text { No. }\end{array}$ & $\begin{array}{l}\text { Capacity } \\
\text { (MW) }\end{array}$ & $\begin{array}{c}\text { Comprehensive water } \\
\text { consumption rate }\left(\mathrm{m}^{3} / \mathbf{M W h}\right)\end{array}$ & $\begin{array}{c}\text { Types of cooling } \\
\text { system }\end{array}$ & $\begin{array}{l}\text { Heat rates } \\
(\text { gce } / \mathbf{k W h})\end{array}$ \\
\hline 247 & 600 & 0.25 & Open-loop & 322.2 \\
\hline 248 & 600 & 0.28 & Open-loop & 306.39 \\
\hline 249 & 600 & 0.22 & Air-cooled & 337.27 \\
\hline 250 & 660 & 0.17 & Open-loop & 308.22 \\
\hline 251 & 600 & 0.26 & Open-loop & 322.76 \\
\hline 252 & 600 & 0.22 & Air-cooled & 338.28 \\
\hline 253 & 630 & 0.39 & Open-loop & 319.89 \\
\hline 254 & 630 & 0.63 & Open-loop & 307.89 \\
\hline 255 & 600 & 0.28 & Open-loop & 313.82 \\
\hline 256 & 600 & 0.19 & Open-loop & 306.97 \\
\hline 257 & 660 & 1.55 & Closed-loop & 308.27 \\
\hline 258 & 660 & 0.24 & Open-loop & 311.67 \\
\hline 259 & 600 & 1.86 & Closed-loop & 315.92 \\
\hline 260 & 660 & 0.31 & Air-cooled & 328.35 \\
\hline 261 & 1000 & 0.31 & Open-loop & 284.56 \\
\hline 262 & 1000 & 0.19 & Open-loop & 295.69 \\
\hline 263 & 600 & 0.40 & Open-loop & 322.3 \\
\hline 264 & 600 & 2.03 & Closed-loop & 310.84 \\
\hline 265 & 600 & 0.40 & Air-cooled & 330.15 \\
\hline 266 & 600 & 2.05 & Closed-loop & 317.36 \\
\hline 267 & 600 & 0.44 & Air-cooled & 344.06 \\
\hline 268 & 660 & 0.50 & Open-loop & 305.45 \\
\hline 269 & 1000 & 0.39 & Open-loop & 294.82 \\
\hline 270 & 660 & 0.30 & Open-loop & 291.2 \\
\hline 271 & 660 & 0.31 & Air-cooled & 324.62 \\
\hline 272 & 600 & 0.31 & Air-cooled & 326.92 \\
\hline 273 & 600 & 0.27 & Air-cooled & 338.92 \\
\hline 274 & 600 & 0.40 & Open-loop & 318.71 \\
\hline 275 & 600 & 0.10 & Open-loop & 313.33 \\
\hline 276 & 600 & 0.20 & Open-loop & 310.75 \\
\hline 277 & 600 & 0.44 & Air-cooled & 344.06 \\
\hline 278 & 600 & 2.10 & Closed-loop & 316.79 \\
\hline 279 & 700 & 0.41 & Open-loop & 321.73 \\
\hline 280 & 700 & 0.49 & Open-loop & 310.74 \\
\hline 281 & 660 & 0.38 & Air-cooled & 328.51 \\
\hline 282 & 600 & 2.08 & Closed-loop & 323.87 \\
\hline 283 & 600 & 1.86 & Closed-loop & 316.44 \\
\hline 284 & 660 & 0.55 & Air-cooled & 325.81 \\
\hline 285 & 600 & 0.40 & Open-loop & 318.23 \\
\hline 286 & 600 & 0.20 & Open-loop & 310.77 \\
\hline 287 & 660 & 0.45 & Open-loop & 303.24 \\
\hline 288 & 600 & 2.07 & Closed-loop & 318. \\
\hline 289 & 600 & 0.27 & Air-cooled & 338.82 \\
\hline
\end{tabular}


Table A1. Cont.

\begin{tabular}{|c|c|c|c|c|}
\hline $\begin{array}{l}\text { Plant } \\
\text { No. }\end{array}$ & $\begin{array}{l}\text { Capacity } \\
\text { (MW) }\end{array}$ & $\begin{array}{c}\text { Comprehensive water } \\
\text { consumption rate }\left(\mathbf{m}^{3} / \mathbf{M W h}\right)\end{array}$ & $\begin{array}{c}\text { Types of cooling } \\
\text { system }\end{array}$ & $\begin{array}{l}\text { Heat rates } \\
\text { (gce/kWh) }\end{array}$ \\
\hline 290 & 600 & 2.16 & Closed-loop & 311.67 \\
\hline 291 & 600 & 0.40 & Open-loop & 324.25 \\
\hline 292 & 600 & 3.83 & Closed-loop & 326.53 \\
\hline 293 & 600 & 0.19 & Open-loop & 306.98 \\
\hline 294 & 600 & 0.26 & Open-loop & 317.15 \\
\hline 295 & 600 & 0.26 & Open-loop & 318.05 \\
\hline 296 & 600 & 0.31 & Air-cooled & 339.33 \\
\hline 297 & 600 & 0.38 & Open-loop & 313.76 \\
\hline 298 & 600 & 0.24 & Open-loop & 303.91 \\
\hline 299 & 1000 & 1.87 & Closed-loop & 291.08 \\
\hline 300 & 1000 & 0.32 & Open-loop & 298.1 \\
\hline 301 & 600 & 1.71 & Closed-loop & 322.59 \\
\hline 302 & 600 & 0.25 & Open-loop & 322.2 \\
\hline 303 & 600 & 1.61 & Closed-loop & 332.22 \\
\hline 304 & 600 & 0.31 & Air-cooled & 326.75 \\
\hline 305 & 630 & 0.39 & Open-loop & 309.04 \\
\hline 306 & 600 & 0.25 & Open-loop & 322.2 \\
\hline 307 & 600 & 0.28 & Open-loop & 308.48 \\
\hline 308 & 630 & 0.42 & Open-loop & 317.64 \\
\hline 309 & 600 & 0.23 & Open-loop & 309.43 \\
\hline 310 & 600 & 1.79 & Closed-loop & 331.2 \\
\hline 311 & 700 & 0.41 & Open-loop & 322.14 \\
\hline 313 & 600 & 0.76 & Closed-loop & 303.75 \\
\hline 314 & 600 & 0.26 & Open-loop & 320.52 \\
\hline 315 & 660 & 1.71 & Closed-loop & 304.94 \\
\hline 316 & 600 & 0.27 & Air-cooled & 339.58 \\
\hline 317 & 600 & 0.76 & Closed-loop & 305.18 \\
\hline 318 & 600 & 0.18 & Air-cooled & 346.8 \\
\hline 319 & 600 & 1.78 & Closed-loop & 316.43 \\
\hline 320 & 600 & 0.23 & Open-loop & 314.1 \\
\hline 321 & 600 & 0.35 & Air-cooled & 349.18 \\
\hline 323 & 800 & 0.51 & Open-loop & 355.23 \\
\hline 324 & 600 & 0.28 & Air-cooled & 341.09 \\
\hline 327 & 600 & 0.25 & Open-loop & 325.51 \\
\hline 328 & 700 & 0.50 & Open-loop & 312.49 \\
\hline 330 & 600 & 0.35 & Air-cooled & 351.6 \\
\hline 331 & 600 & 0.28 & Air-cooled & 339.29 \\
\hline 333 & 600 & 0.27 & Air-cooled & 333.16 \\
\hline 334 & 600 & 0.18 & Air-cooled & 346.8 \\
\hline
\end{tabular}

\section{Conflicts of Interest}

The authors declare no conflict of interest. 


\section{References}

1. Li Keqiang: Industry in the East has to Move to the West, and a Ban on New Thermal Power in Beijing, Tianjin and Other Regions. Available online: http://news.bjx.com.cn/html/20140626/ 521911.shtml (accessed on 26 June 2014).

2. China Electricity Council (CEC). Annual Development Report on China's Power Industry; China Market Press: China, Beijing, 2013.

3. China Electricity Council (CEC). Power Development Strategic Research Report, 2013. Available online: http://www.doc88.com/p-8015468257297.html (accessed on 20 August 2014).

4. The Fifth Session of the Seventeenth CPC Central Committee. Economic and Social Development 12th FYP, 2011. Available online: http://www.gov.cn/2011h/content_1825838.htm (accessed on 20 August 2014).

5. The State Council. The 12th Energy Development plan, 2013. Available online: http://wenku.baidu.com/ link?url=cVcFR_cw1iXEDQ4XkOiRSlb23mSeZ12d6GpRzNF7QkDhzFpW8w6Rq0ikPcOSofYj0v-V6IH2a9zj8g1H4nVba6Wp_FKpo8n3KGxp188fbK (accessed on 20 August 2014).

6. National Energy Administration. The 12th Coal Industry Development plan, 2012. Available online: http://finance.qq.com/a/20120322/005082.htm (accessed on 20 August 2014).

7. International Energy Agency. IEA Energy Statistics-Electricity for World. Available online: http://www.iea.org/stats/electricity-data.asp?COUNTRY_CODE=29 (accessed on 20 August 2014).

8. Rebetez, M.; Dupont, O.; Girond, M. An Analysis if the July 2006 Heatwave Extent in Europe Compared to the Record Year of 2003. Available online: http://china.springerlink.com/content/ y5rk72801647k547/?p=a484fa0be21d4cad8d361b2b6c22eaca\&pi=0 (accessed on 20 August 2014).

9. UN-Water. Coping with Water Scarcity: An Action Framework for Agriculture and Food Security; Food and Agriculture Organization of the United Nations: Rome, Italy, 2012.

10. Carter, N.T. Energy's Water Demand: Trends, Vulnerabilities, and Management; Diane Publishing Company: Collingdale, PA, USA, 2010.

11. Kajenthira, A.; Siddiqi, A.; Anadon, L.D. A new case for promoting wastewater reuse in Saudi Arabia: Bringing energy into the water equation. J. Environ. Manag. 2012, 102, 184-192.

12. Siddiqi, A.; Kajenthira, A.; Anadón, L.D. Bridging decision networks for integrated water and energy planning. Energy Strategy Rev. 2013, 2, 46-58.

13. Gleick, P.H. Water and energy. Annu. Rev. Energy Environ. 1994, 19, 267-299.

14. Bazilian, M.; Rogner, H.; Howells, M.; Hermann, S.; Arent, D.; Gielen, D.; Steduto, P.; Mueller, A.; Komor, P.; Tol, R.S.J.; et al. Considering the energy, water and food nexus: Towards an integrated modelling approach. Energy Policy 2011, 39, 7896-7906.

15. Koch, H.; Vögele, S. Dynamic modelling of water demand, water availability and adaptation strategies for power plants to global change. Ecol. Econ. 2009, 68, 2031-2039.

16. Alexander, T.D.; Melissa, M.B. The Regional Energy \& Water Supply Scenarios (REWSS) model. Part I: Framework, procedure, and validation. Sustain. Energy Technol. Assess. 2014, 7, 227-236.

17. Benjamin, K.S.; Kelly, E.S. Identifying future electricity-Water tradeoffs in the United States. Energy Policy 2009, 37, 2763-2773.

18. Edward, A.B.; Jim, W.H.; Jaime, M.A. Electricity generation and cooling water use: UK pathways to 2050. Global Environ. Chang. 2014, 25, 16-30. 
19. Aurelie, D.; Edi, A.; Stephanie, B.; Sandrine, S.; Nadia, M. Water modeling in an energy optimization framework - The water-scarce middle east context. Appl. Energy 2013, 101, 268-279.

20. Kuishuang, F.; Klaus, H.; Yim, L.S.; Xin, L. The energy and water nexus in Chinese electricity production-A hybrid life cycle analysis. Renew. Sustain. Energy Rev. 2014, 39, 342-355.

21. Huang, X. On the Status of Water in China. Dossier 2013, 3, 185.

22. Alun, G.; Fei, T.; Yu, W. China energy-water nexus: Assessing the water-saving synergy effects of energy-saving policies during the eleventh Five-year Plan. Energy Convers. Manag. 2014, 85, 630-637.

23. Zhang, Z.; Bai, J.; Zhen, H. Distributing water resources optimumly and promoting the development of coal power bases. Electric Power 2007, 40, 20-24.

24. Institute of Geographical Sciences and Natural Resource Research, Chinese Academy of Sciences, Land Key Laboratory of Water Cycle and Surface Process. Thirsty Coal; China Environmental Science Press: Beijing, China, 2012.

25. Wei, X; Liu, F. A brief analysis of protection and sustainable use of water resources in Inner Mongolia Jungar Banner. Shanxi Architect. 2010, 36, 362-363.

26. Tuo, Y. Saving water and promoting sustainable use of water resources in Inner Mongolia. Inner Mongolia Water 2009, 3, 87-88.

27. Water Resources in Holingola. Available online: http://www.hlgls.gov.cn/userlist/admin/newshow7304.html (accessed on 06 June 2013).

28. National Bureau of Statistics of China. China Economic Census Yearbook 2008; China Statistics Press: Beijing, China, 2008.

29. Jiang, Y. China's water scarcity. J. Environ. Manag. 2009, 90, 3185-3196.

30. National Bureau of Statistics of China. China Statistical Yearbook 2013; China Statistics Press: Beijing, China, 2013.

31. Department of Energy. Energy Demands on Water Resources-Report to Congress on the Interdependency of Energy and Water. Available online: http:/climateknowledge.org/figures/ Rood_Climate_Change_AOSS480_Documents/DoE_Energy_Water_Resources_2006.pdf (accessed on 20 August 2014).

32. Cammerman, N. Integrated Water Resource Management and the Water, Energy, Climate Change Nexus. Available online: http:/www.watercentre.org/resources/publications/attachments/ ncammerman (accessed on 20 August 2014).

33. Rio Carillo, A.M.; Frei, C. Water: A key resource in energy production. Energy Policy 2009, 37, 4303-4312.

34. US Geological Survey (USGS). Estimated Use of Water in the United States in 2000. Available online: http://pubs.usgs.gov/circ/2004/circ1268/index.html (accessed on 20 August 2014).

35. Cheng, Z.; Wen, Z. Water resources utilization of thermal power plant. Manag. J. 2011, 17, 375.

36. Electric Power Research Institute (EPRI). US Water Consumption for Power Production-The Next Half Century. Available online: http://www.circleofblue.org/waternews/wp-content/uploads/ 2010/08/EPRI-Volume-3.pdf (accessed on 20 August 2014).

37. Meldrum, J.; Nettles-Anderson, S.; Heath, G.; Macknick, J. Life cycle water use for electricity generation: A review and harmonization of literature estimates. Environ. Res. Lett. 2013, doi:10.1088/1748-9326/8/1/015031. 
38. Thomas, J.F., III; Timothy, J.S.; Gary, J.S., Jr.; Andrea, M.; Michael, N.; Brian, S.; James, T.M.; Lynn, M. Water: A critical resource in the thermoelectric power industry. Energy 2008, 33, 1-11.

39. China Electricity Council (CEC). Notification of energy efficiency benchmarking and competition data of 2012 national 600MW thermal power units. Available online: http://kjfw.cec.org.cn/ kejifuwu/2013-04-07/99877.html (accessed on 20 August 2014).

40. Wang, H.; Nakata, T. Analysis of the market penetration of clean coal technologies and its impacts in China's electricity sector. Energy Policy 2009, 37, 338-351.

41. Li, H.; Chien, S.H.; Hsieh, M.K.; Dzombak, D.A.; Vidic, R.D. Escalating water demands for energy production and the potential for use of treated municipal wastewater. Environ. Sci. Technol. 2011, $45,195-200$.

(C) 2014 by the authors; licensee MDPI, Basel, Switzerland. This article is an open access article distributed under the terms and conditions of the Creative Commons Attribution license (http://creativecommons.org/licenses/by/4.0/). 